【論 文】

UDC : 550.34 .04

\title{
小地震の加速度包絡波形の合成による 大地震の最大加速度の推定
}

\section{1.はじめに}

地震動の最大加速度を推定するために，強震記録の統 計解析による最大加速度の距離减衰式が多数提案されて きだ。しかしながら，大地震の近距離での記録はわずか しか得られていないため,これらの距離減衰式を用いて 大地震による近距離での最大加速度を推定しても, 用い たデー夕を大きく外挿したことになり，信頼性の高い結 果か得られるとは限らない。

近年，大地震による近距離での地震動を推定する方法 として, 余震合成法が用いられ，良好な結果が得られて

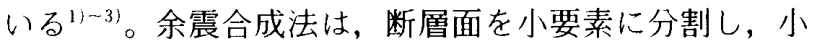
要素に対応する要素地震の波形を適当な時間差を与えて 足し合わせることにより大地霞の波形を合成するもので ある。この方法を用いようとする際に，対象とする地点 で要素地震に対応する観測波形が利用できる場合は限ら れているため, 要素地震の波形を模擬的に発生させて, これらを重衫合わせることも試みられているい。しかし， 波形を模擬的に発生させるためにはそのスペクトル特性 や位相特性なゼ多数の特性值を定めることが必要とされ る。そのため, 計算の過程がかなり煩雑となったり，計 算結果の不確定性が増大したりするものと考えられる。

筆者らも，余震合成法之類似の考えに基づいて断層面 の各小要素からの包絡波形を重㸚合わせることにより， 大地震の包絡波形を合成する手法を提案した ${ }^{5 !}$ 。この手 法による計算結果は震源近傍での観測記録のスペクトル や震源域周辺の震度分布とよい一致を示すものの ${ }^{5 /, 61}$, 小要素からの包絡波形を定める規則において物理的な意 味があいまいな部分もある。そのため，計算の際に断層 面での複雑な破壊分布などを考慮することがそのままで は困難であることも指摘されている゙。

本研究では，その物理的意味が明確にされている余震 合成法の合成規則を用いて，要素地震の波形の代わりに その加速度包絡波形を重权合わせることにより，大地震 の加速度包絡波形を合成し，大地震時の最大加速度を推 定することを試みた。さらに，計算された最大加速度の

* 東京工.業大学: 助教授・工博（現在：チリカトリカ大学滞 在中)

(1988 年 8 月 30 日原稿受理，1989年1月12 日採用决定)
正会員 翠 川 三 郎*

距離減衰特性についても考察した。

\section{2. 合成手法}

加速度を支配する短周期領域での震源スペクトルが $\omega$ 2 乗モデルに従うものと仮定すると²)，このモデルを満 足する田中ら ${ }^{3)}$ の方法から，（1）式に示すように，要 素地震の加速度波形 $a_{i}(t)$ の重祸合わせにより大地震の 加速度波形 $A(t)$ が合成できる（図一1(a) 参照）。

$$
A(t)=\sum_{i=1}^{n} a_{i}\left(t+T_{i}\right)
$$

ここで， $T_{i}$ は，要素地震が発生する各小要素から観 测点までの走時および各要素の破壊開始時刻の違いに よって生ずる時間ずれで, 要素数 $n$ は, 大地震の地震 規模 $M$ と要素地震の地震規模 $M^{\prime}$ の差から次式により 決められる31。

$$
n=10^{M-}
$$

（1）式の両辺を 2 乗すると,

$$
\begin{aligned}
A^{2}(t)= & \left\{\sum_{i=1}^{n} a_{i}\left(t+T_{i}\right)\right\}^{2}=\sum_{i=1}^{n} a_{i}^{2}\left(t+T_{i}\right) \\
& +\sum_{i \neq j} a_{i}\left(t+T_{i}\right) a_{j}\left(t+T_{j}\right) \cdots \ldots \ldots .
\end{aligned}
$$

ここで，右辺の第 2 項目を $C(t)$ とおくと，

$$
\begin{aligned}
C(t) & =\sum_{i \neq j} a_{i}\left(t+T_{i}\right) a_{j}\left(t+T_{j}\right) \\
& =\sum_{i \neq j} a_{i}\left(t+T_{i}\right) a_{j}\left(t+T_{i}+\left[T_{j}-T_{i}\right]\right) \cdots(4)
\end{aligned}
$$
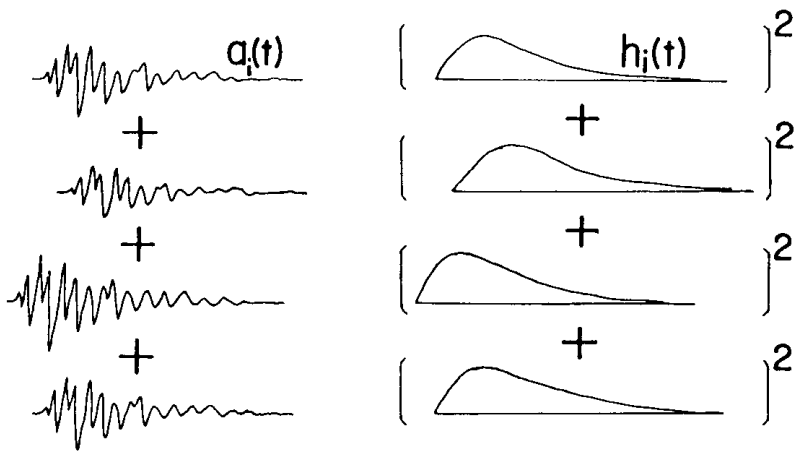

II

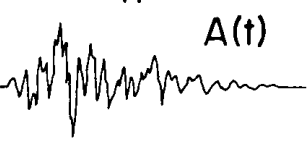

(a)

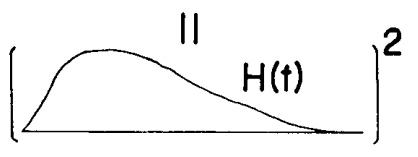

(b)

図一1 通常の余震合成法 (a) と本合成手法（b) の比較 
断層近くでは走時および破壊開始時刻の違いによって 生ずる時間ずれ $T_{i}$ の值はみかけ上ランダムになる2)。 観測点が遠方にある場合でも，断層を等分割することに よる周期性が $T_{i}$ に現れるものの, 要素 $i$ の時間ずれ $T_{i}$ と要素 $j$ の時間ずれ $T_{j}$ の差 $\left[T_{i}-T_{j}\right]$ の分布にはある大 きさのゆらぎが生ずるはずである。このゆらぎの大きさ はそれぞれの場合で異なるが，加速度波形を支配する周 期 $(0.5 \text { 秒以下 })^{8)}$ に比べて,このゆらぎの大きさが十 分に小さいとは考え難い。そこで，加速度波形を支配す る周期領域では $a_{i}\left(t+T_{i}\right)$ と $a_{j}\left(t+T_{j}\right)$ の位相差はラン ダムとみなせ， $a_{i}\left(t+T_{i}\right)$ と $a_{j}\left(t+T_{j}\right)$ の相関は無視で きる。したがって， $C(t)$ は 0 と仮定でき, 合成される 加速度波形の 2 乗振幅 $A^{2}(t)$ は次式で近似できる。

$$
A^{2}(t)=\sum_{i=1}^{n} a_{i}^{2}\left(t+T_{i}\right)
$$

要素地震の加速度波形 $a_{i}(t)$ および合成される加速度 波形 $A(t)$ の絶対值をとったものをそれぞれ $b_{i}(t)$ および $B(t)$ とすれば， (5) 式から以下の式がなりたつ。

$$
B(t)=\sqrt{\sum_{i=1}^{n} b_{i}^{2}\left(t+T_{i}\right)} \cdots
$$

さらに， $b_{i}(t)$ および $B(t)$ のピークをそれぞれつなげ て得られる包絡波形 $h_{i}(t)$ および $H(t)$ についても上式 は近似的に成立し, 大地震の加速度波形の包絡波形 $H(t)$ は要素地震の加速度波形の包絡波形 $h_{i}(t)$ を用いて 次式により合成できる（図一1(b) 参照)。

$$
H(t)=\sqrt{\sum_{i=1}^{n} h_{i}^{2}\left(t+T_{i}\right)} \cdots
$$

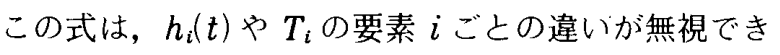
る場合には $H(t)$ は $h_{i}(t) の \sqrt{n}$ 倍となることを意味す る。結局, (6) 式より大地震の加速度包絡波形を得る ためには, 要素地震の加速度包絡波形 $h_{i}(t)$ のみを規定 すればよい。この $h_{i}(t)$ について, 次式のようにその最 大值 $a_{i}$ 之包絡形状 $f_{i}(t)$ にわけて考える。

$$
h_{i}(t)=a_{i} \times f_{i}(t)
$$

$a_{i}$ は, 既往の最大加速度の経験式を用 いて規定する。ここでは，日本の強震記録 から得られた地震規模 $M$ と震源距離 $X$ $(\mathrm{km})$ をパラメータとした田中・福島”に よる最大加速度 $A\left(\mathrm{~cm} / \mathrm{s}^{2}\right)$ の経験式を用 いることとする。この式を以下に示す。

\section{$\log A=0.40 M-\log X$}

$$
-0.00164 X+1.18 \cdots(8)
$$

$f_{i}(t)$ については実際には複雑な形状を 示す場合もあろうが,ここでは簡単のため, Kameda and Sugito ${ }^{10)} に な ら っ て t_{p}$ をパ ラメータとして次式のように関数化する。

$$
f_{i}(t)=t / t_{p} \quad \exp \left(1-t / t_{p}\right) \cdots(9)
$$

要素地震に相当する比較的地震規模の小
さい地震の強震記録を（9）式に当てはめて， $t_{\boldsymbol{p}}$ を求 めてみると図一2のようになる。ここで用いた強震記録 は, 1979 年 Imperial Valley 地震の余震 $\left(M_{L}=5.0\right)^{11)}$, 1983 年の神奈川一山梨県境の地震 $(M=6.0)^{12)}$, およ び 1986 年 Parm Springs 地震 $\left(M_{L}=6.0\right)^{13)}$ によるもの である。これらのデータから， $M$ と $X$ をパラメータと した $t_{\rho}($ 秒) の経験式が次式のように求まる。

$$
t_{p}=0.015 \times 10^{0.5 M}+0.12 X^{0.75} \cdots
$$

(10) 式の結果を $M 5$ および 6 の場合について図 -2 の実線で示す。

これらの式を用いて，以下の手順で計算が行える。

1）大地震の地震規模 $M$, 断層面の大きさ, 位置お よび破壊伝搬形式を設定する。

2）合成に用いる要素地震の地震規模 $M^{\prime}$ から, (2) 式より要素数 $n$ を決め，断層面を $n$ 個に分割する。

3）要素地震の地震規模 $M^{\prime}$ 亡各要素から観測点まで の距離 $X_{i}$ を（8）および（10）式に代入して，そ れぞれ $a_{i}$ および $t_{\rho}$ を求め,さらに(9)および $(7)$ 式を用いて各要素地震の加速度包絡波形 $h_{i}(t)$ が得 られる。

4）これらを（6）式に基づいて重ね合わせることに より大地震の加速度包絡波形 $H(t)$ が求まり, その 最大值から大地震の最大加速度が得られる。

ここで, 要素地震の地震規模 $M^{\prime}$ としては震源が点と みなせるよう小さなものが望ましいが, 余震合成法の 基本である地震のスケール則が成立することが確認され ている地震規模の範囲 ${ }^{14)}$ や（8）・(10）式を作製する際 に用いられた記録の地震規模の範囲などを考慮して, $M^{\prime}$ を 5.5 とした。また，（8）式は震源距離 $20 \mathrm{~km}$ 以 上の記録に基づいて作製されたものである91ので，距離 がこれより小さい場合にこの式を適用することはデー夕 を外挿することとなる。しかし，地震規模が 5.5 と小さ いので, 距離が小さくても大きな誤りは犯さないのもの と考え, 距離 $X_{i}$ が数 $\mathrm{km}$ 以上となる範囲で計算を行っ 
た。

\section{3. 鉛直断層の場合の最大加速度の距離隇衰}

本手法による結果の妥当性を検討するために, 地震規 模に対して標準的なパラメータを持つ鉛直断層の地震を 想定して計算を行った。M 5.5 の要素地震の断層面の長 さおよび幅は, 地震規模と断層面の面積の関係式 ${ }^{14)}$ を参 考にして,それぞれ $6.7 \mathrm{~km}$ および $3.35 \mathrm{~km}$ とした。(2) 式より，この要素地震の断層面を長さおよび幅方向に 3 倍ずつ拡大したものが $M$ 6.5 の地震に相当し， 7 倍ずつ 拡大したものが $M 7.2$ の地震に相当する。また，M7.7 のものとして, 長さ方向に 15 倍, 幅方向に 10 倍拡大し たものを考えた。これは，長さおよび幅方向に同じ倍率 で拡大すると，鉛直な断層面の場合には断層面の下端が 地殼を越えてマントルまで至ってしまい, 現実的なモデ ルとは考え難くなるためである。なお，断層面上端の深

\section{$M=7.2$}

UNILATERAL $\delta=90^{\circ}$

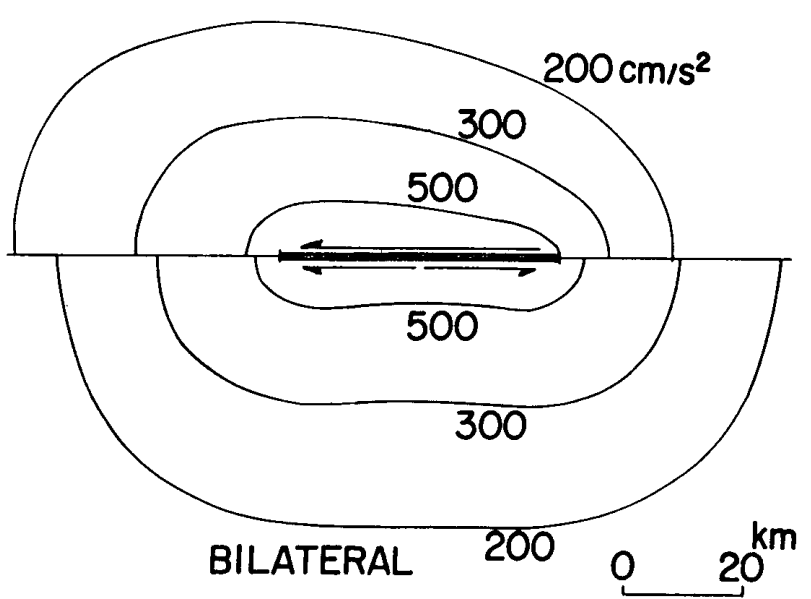

图一3 鉛直断層の場合の最大加速度分布

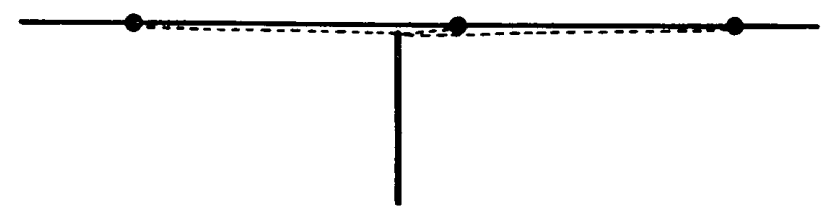

\section{VERTICAL DIP}

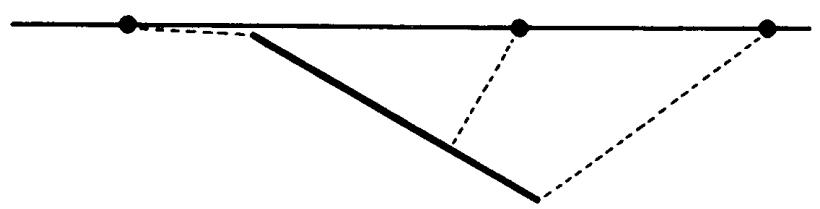

LOW ANGLE DIP

図一4 震源からの距離の定義
さを $2 \mathrm{~km}$, 破壊伝搬速度を $2.5 \mathrm{~km} / \mathrm{s}$ ，地震波の伝搬速 度を $3.5 \mathrm{~km} / \mathrm{s}$ とした。

図一 3 に，M 7.2 の地震の 1 方向破壊伝般之両方向破 壊伝搬の場合の最大加速度分布の比較を示す。両方向破 壊伝搬の場合には, 最大加速度はほぼ断層からの距離と ともに減衰している。1 方向破壊伝搬の場合には，破壊 伝搬の影響により，破壊が遠ざかる方向では振幅がかな り小さく, 破壊が近づく方向で振幅がやや大きくなって いる。しかし，破壊が遠ざかる方向を除くと，方向によ る振幅の違いはそれほぼ大きなものではなく, 両方向破 壊伝搬の場合と顕著な相違はない。

そこで, 両方向破壊伝搬の場合の最大加速度の距離減 衰の特性について検討した。震源からの距離の定義とし て, 震央距離, 震源距離のほかに, 断層線からの最短距 離が用いられる場合が多い。しかし，断層線からの最短 距離では, 後述する低角断層の場合に断層面の上盤側之 下盤側を区別できないので，図一4に示すように，断層 面からの最短距離を震源からの距離として採用すること にした。ただし，この定義による距離は鉛直断層の場合 には断層線からの最短距離とほとんど変わらない。

両方向破壊伝搬の場合の最大加速度の距離減衰を図一 5 に示す。図中の減衰曲線の幅は，断層からの方向によ る違いを示している。Mの小さな地震ほど幅が大きい のは， $M^{\prime}$ を固定しているために $M$ が小さくなるほど 要素地震の分割が相対的に粗くなるためとも考えられる が，いずれにせよ方向による振幅の違いは小さい。この

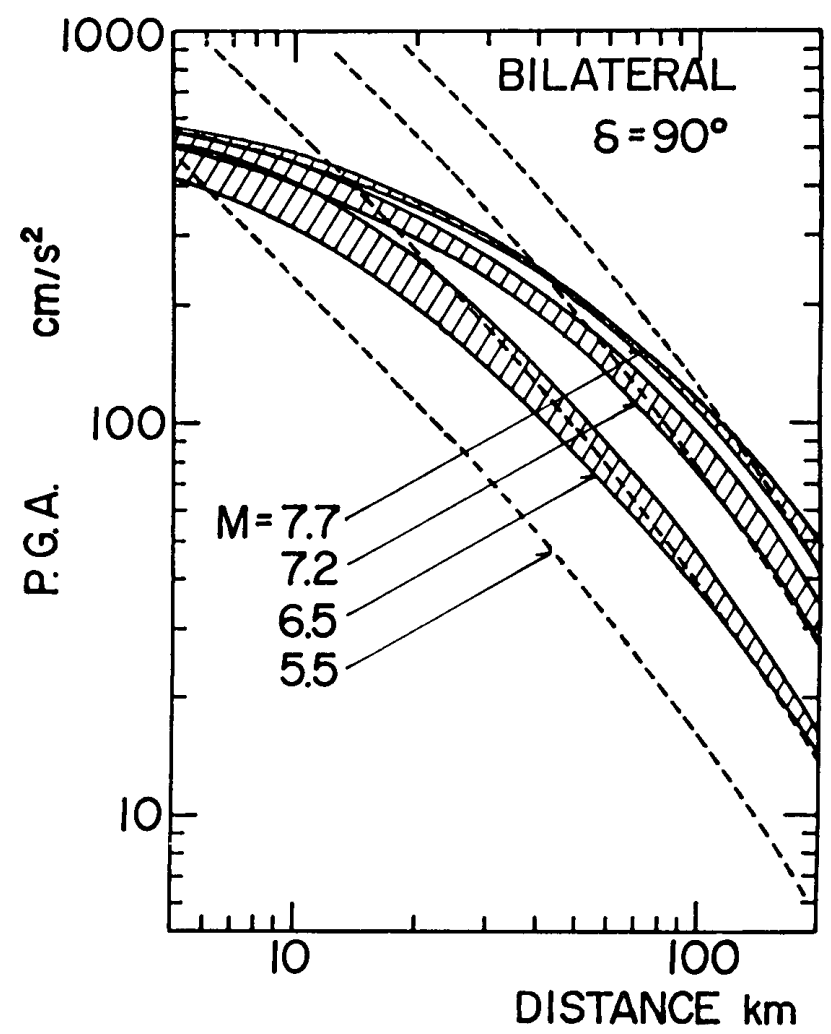

図一5 鉛直断層の場合の最大加速度の距離減衰曲線 


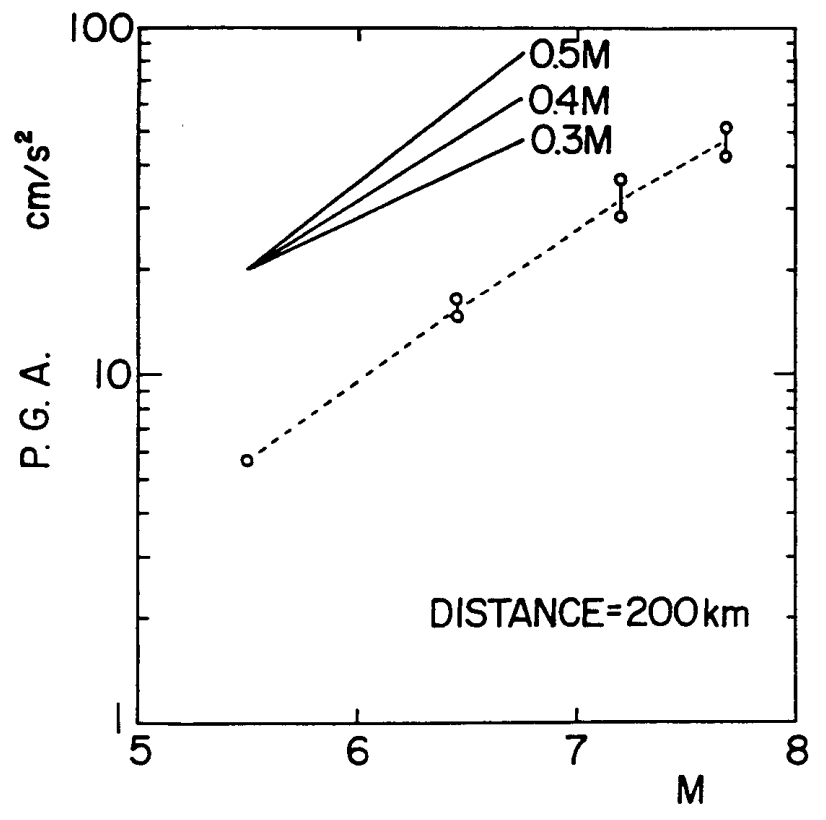

図一6断層から離れた地点での最大加速度の $M$ 依存性

結果は（8）式から得られる $M 5.5$ の場合の最大加速 度值の合成によるものである。そこで，（8）式から得 られるそれぞれの $M$ の場合の距離減衰曲線を描くと, 図一 5 の点線のようになる。距離が大きいところでは, 合成によって得られた減衰曲線は（8）式の減衰曲線と ほぼ一致する。

図一6は距離が $200 \mathrm{~km}$ での合成された最大加速度の $M$ 依存性を示したもので, 最大加速度の対数はおおむ ね $M$ の 0.4 倍に比例して增大している。この值は既往 の最大加速度の経験式にみられる $M$ 依存性の係数の平 均的な值とほぼ一致する9)。これらのことは距離の大き いところでの本合成手法による結果の妥当性を示してい る。

一方, 距離が小さいところでは, 合成による結果の方 が（８）式よりも小さな值を示し, 距離が非常に小さく なると $M$ によらずある值 $\left(600 \mathrm{~cm} / \mathrm{s}^{2}\right.$ 程度 $)$ に収束す る傾向が認められる（図一5参照）。すなわち, 距離が それぞれの断層長さより小さくなると，距離減衰の傾き は（8）式に比べ小さくなる。既往の距離減衰式におい ては, 減衰曲線の形状は一定で, 地震規模により振幅が 上下するものが多いが, 本計算結果においては減哀曲線 の形状は地震規模により変化している。

Campbel1 ${ }^{15)}$ や表ら $^{16)}$ は, それぞれ, そのほとんどが 鉛直断層の地震による観測記録および墓石の転倒状況か ら, 断層付近での最大加速度の距離減衰曲線を示してい る。図一7に示すように，断層付近での観測值に基づく Campbell および表らによる减衰曲線の形状も, 図一5 と同様に地震規模により変化している。特に, Campbell の減衰曲線は図一5に示した本手法による結果とほ とんど同じ形状を示している。

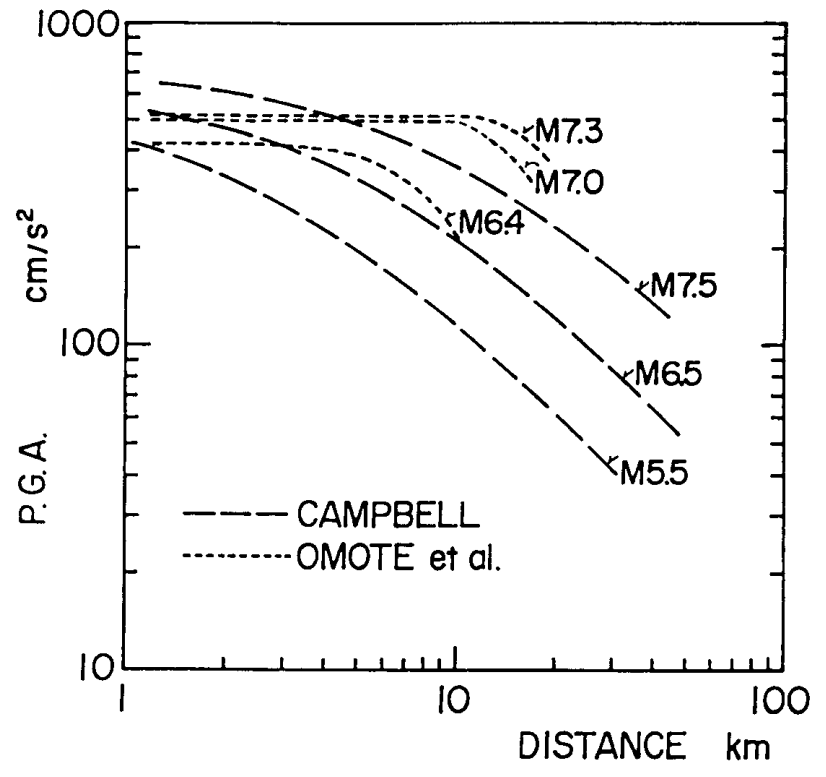

図一7断層付近での観測値に基づく距離隇衰曲線

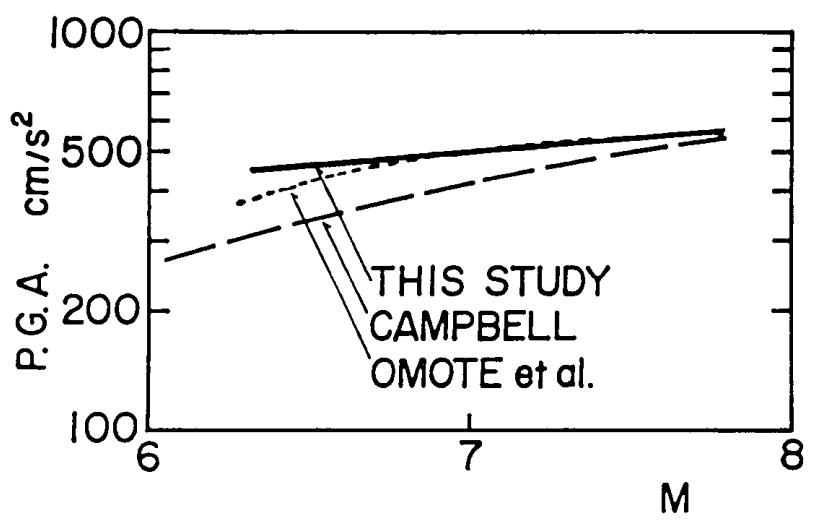

図一8 断層付近での最大加速度の $M$ 依存性

図一8は, 距離が $5 \mathrm{~km}$ での最大加速度の比較を示し たものである。いずれの場合も距離が小さいところでは， 最大加速度の $M$ 依存性が小さいことを示している。こ れらのことは, 本手法による結果が断層付近での観測結 果にみられる全般的な傾向を満足しており, 距離の小さ いところでの本合成手法による結果が妥当であることを 示唆している。ただし, 図一8に示した断層付近での最 大加速度の值は小地震の距離減衰曲線として（8）式を 用いた場合の結果であり, この值は用いる距離減衰式に よってある程度変化することに注意する必要がある。

\section{4. 低角断層の場合の最大加速度の距離隇衰}

前述の結果は鉿直断層の地震によるものであり, 低角 断層の地震の場合には異なる結果が得られる場合がある ものと考えられる。低角断層の場合, 断層面の傾斜角が 新たなパラメータとして追加されるが，ここでは傾斜角 を $30^{\circ}$ とした。前述の要素地震の断層面を長さおよび幅 方向に 3 倍， 7 倍，15 倍ずつ㹡大し，それぞれ $M 6.5$, 7.2, 7.9 の地震の最大加速度を合成した。その他のパラ メー夕は鉛直断層の場合と同一のものを用いた。

図一 9 に, M 7.2 の地震の 1 方向破壊伝搬之両方向破 


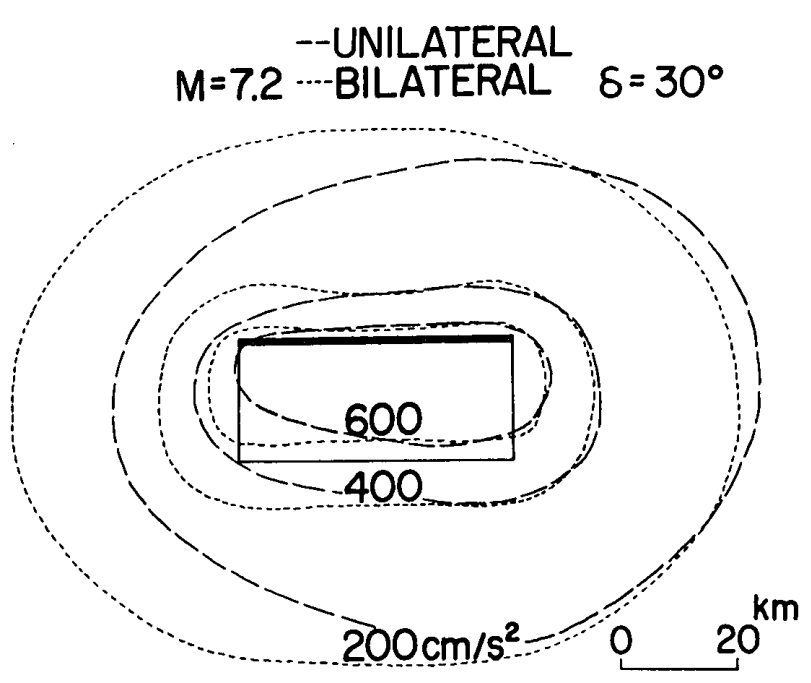

図一9 低角断層の場合の最大加速度分布

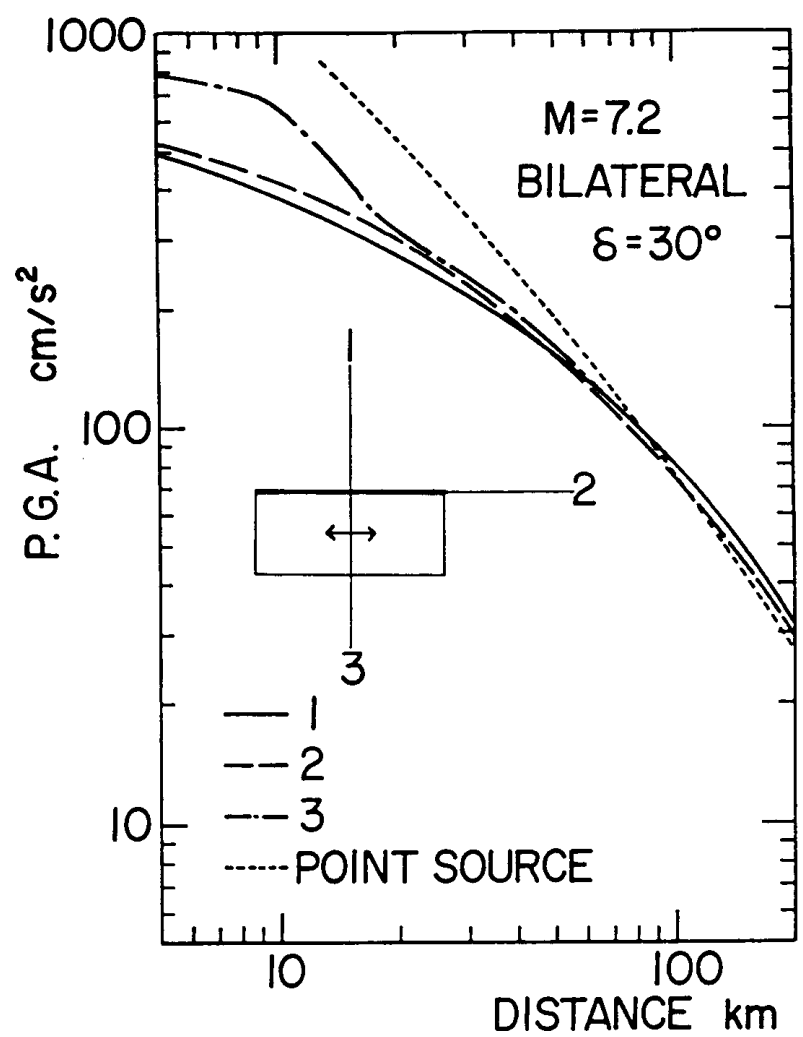

図--10 低角断層の場合の最大加速度の距離減衰曲線

壊伝搬の場合の最大加速度分布の比較を示す。図中の長 方形が断層面の投影を表し，太線が断層面の最も浅い部 分を表す。図一 3 に示した鉛直断層の場合に比べて，断 層面の下盤側ではやや小さめの值を示すが分布形状は同 様である。しかし，上盤側ではかなり大きな值を示して いる。破壊伝搬の影響は鉛直断層の場合之同様で，1 方 向破壊伝搬の場合には，破壞が遠ざかる方向では振幅が かなり小さく，破壊が近づく方向で振幅がやや大きく なっている。

両方向破壊伝般の場合の M 7.2 の地震の最大加速度 の距離減衰を図一10に示す。図には断層の走行方向（破
線）および断層の中央から直交方向（実線および一点鎖 線）での結果が示されている。図中の点線は（8）式よ り得られるM7.2 の場合の減衰曲線を表す。距離が 20 $\mathrm{km}$ 以上の場合には方向による違いはほとんどなく，前 述の鉛直断層の場合ともおおむね一致する。しかし，一 点鎖線で示した断層面の直上を通る方向では，20 km 以 下すなわち直下に断層面が存在する距離になると, 最大 加速度はかなり大きくなり $800 \mathrm{~cm} / \mathrm{s}^{2}$ 程度にまで増大す る。これは，低角断層の上盤側ではそれぞれの要素地震 からの距離の差が小さいために振幅の大きな部分が重な り合って観測点に到達するためと考えられる。例えば, 距離が $10 \mathrm{~km}$ の場合, 各要素地震の最大加速度は 230 $\mathrm{cm} / \mathrm{s}^{2}$ ないしそれ以下であるのに対し，合成結果は 700 $\mathrm{cm} / \mathrm{s}^{2}$ 程度となる。

$M 6.5$ および 7.9 の地震の場合にも同様に，直下に断 層面が存在する位置では最大加速度は顕著に増大する が，それ以外では鉛直断層の結果とほぼ一致し，方向に よる大きな違いもほとんど認められない。したがって， 観測点が断層面の直上にある場合を除けば，震源からの 距離を断層面からの最短距離にとることによって，ある 地震規模 $M$ に対する距離減衰曲線は断層の形状や方位 によらずほぼ一義的に定まることになる。ただし，1方 向破壊伝搬の場合には前述の破壊伝般の効果も考慮する 必要がある。

そこで，図一5に示した両方向破壊伝搬の鉛直断層の 場合の減衰曲線を低角断層の場合も含めて代表的なもの であるとみなし，この減衰曲線が Campbell のそれと相 似であることから，図一5 の減衰曲線を Campbell が採 用した関数形に当てはめてみた。つまり，（8）式の距 離 $X$ に $D(M)$ を加え, $D(M)$ と定数項を図一5 の結果に 基ついて決植した。この $D(M)$ は距離の小さいところ で過大な加速度值が生じないようにするために導入され た值で，これに $M$ 依存性を持たせているので, 減衰曲 線の形状は $M$ によって変化する。結果を次式に示す。

$$
\begin{aligned}
& \log A= 0.40 M-\log \{X+D(M)\} \\
&-0.00164\{X+D(M)\}+1.31 \cdots \\
& \text { ただし, } \log D(M)=0.37 M-1.33
\end{aligned}
$$

上式より, $D(M)$ の值は, $M 6$ で $8 \mathrm{~km}, M 8$ で $43 \mathrm{~km}$ となる。

この式は，合成結果に基ついて（8）式を断層近傍ま で適用できるよう修正したものに相当する。ただし，低 角断層の場合の断層面の直上の観測点に対してはこの式 から求まる值よりも最大加速度は大きく, 例えば傾斜角 が $30^{\circ}$ の場合には 5 割程度大きくなる。また，1方向破 壊伝搬の場合には破壊が近づく方向ではこの式からの值 の1〜2 割大きい值を, 破壊が遠ざかる方向では 3 4 割 小さい值を示す（図一 3 および 9 参照)。 


\section{5. 一様でない破壊分布を持つ地震の 最大加速度分布の計算}

巨大地震の場合，断層面上での破壊の 大きさが一様とみなせない場合が少なく ない吾)。このような場合の計算手順を， 1923 年関東地震を例にとって, 示す。

Matsu'ura らの断層モデル ${ }^{18)}$ を参考と して, 図一11に示すような長さ $85 \mathrm{~km}$, 幅 $50 \mathrm{~km}$, 傾斜角 $25^{\circ}$ の断層面を設定し, 破壊は図の $\otimes$ 印から東南東へ $2 \mathrm{~km} / \mathrm{s}$ の 速度で伝搬するものとした。この地震の $M$ は 7.9 であるので，（2）式より要素 数は約 250 之規定される。この地震の断 層面上のすべり量は一様ではなく，断層 面の西側では東側の部分に比べてすべり 量は約 2 倍とされている ${ }^{18)}$ た，要素地 震を断層面全体に均一に分配することは 合理的とは考え難い。そこで，要素地震 を断層面上での破壊の大きさに応じて分 配することとした。

この分配の際の規則にはいくつかの考 え方があろうが，ここでは以下のような 考え方で分配することとした。地震規模 と地震モーメントの関係 ${ }^{(4)}$ を介すると

(2) 式から地震モーメントと要素数は おおむね比例関係にあるものとみなせ る。すべり量の大きさは単位面積当たり の地震モーメントに相当するので，すべ り量と単位面積当たりの要素地震の数は

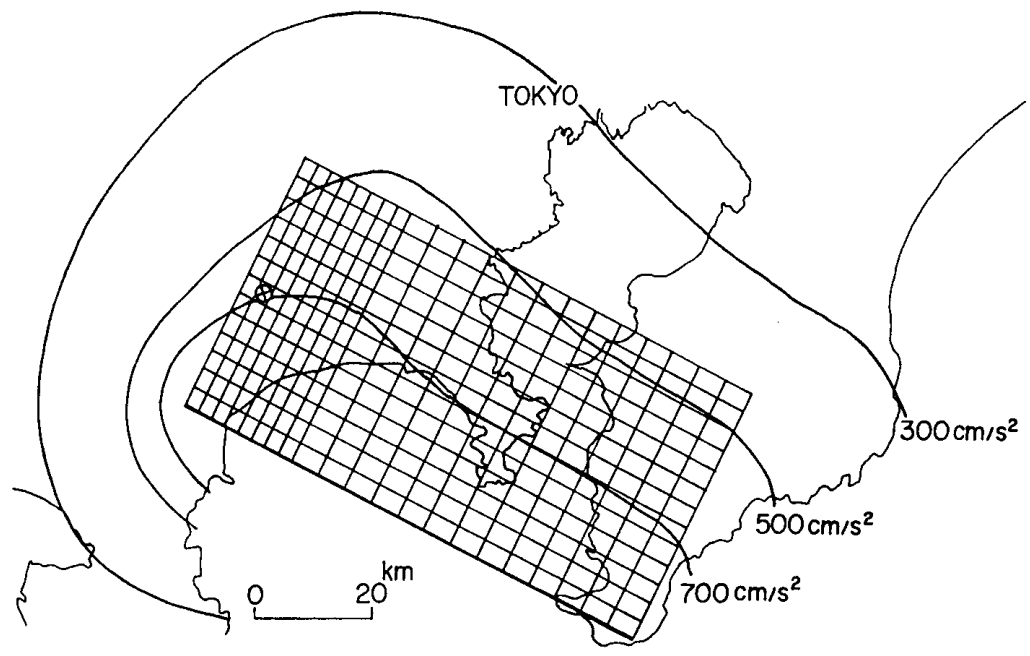

図一11 1923 年関東地震の最大加速度分布（地盤の増幅を考慮しない場合）

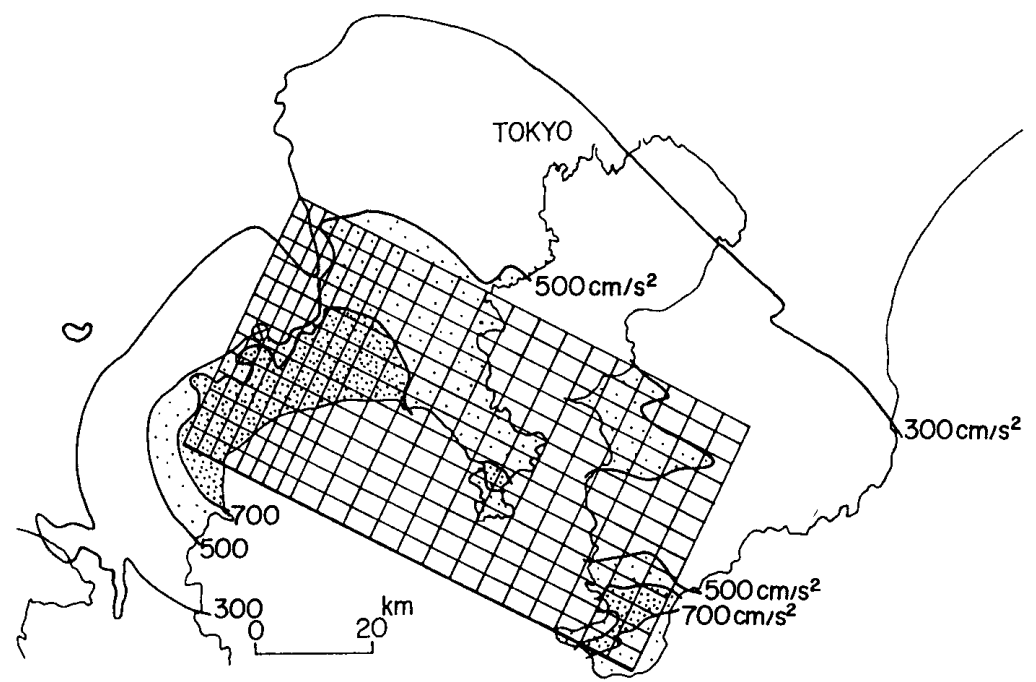

図一12 1923 年関東地震の最大加速度分布（地盤の増幅を考慮した場合） 比例関係にあるものとみなせる。そこで，西側の長さ $20 \mathrm{~km}$ の部分を東側の長さ $65 \mathrm{~km}$ の部分に比べて長さ方 向に 2 倍細かく分割し，単位面積当たりの分割数を 2 倍 とした。結局，全分割数を 273 分割（西側 104 分割，東 側 169 分割）として計算した。

得られた最大加速度分布を図一11に示す。断層面の 西側に要素地震を多く分配したため，この最大加速度分 布は断層面の西側でやや大きく，破壊が東に伝搬した影 響は最大加速度分布には認められない。この結果は，そ れぞれの地形別に整理したこの地震の木造家屋の被害率 と距離の関係に方位依存性が認められないこと191とよく 符合している。

図一11の結果は（8）式に示す距離減衰式に基づく ものであるから，標準的な地盤に対する値と考えられ， 各地点での地盤の増幅の効果は考虑されていない。そこ で，第四紀から第三紀にかけての地盤が（8）式に対応 する標準的な地盤と考え，各地質区分と地盤の増幅率の 関係 ${ }^{6}$ を利用すると, 第四紀層, 第四紀噴出物層, 第三 紀層, 先第三紀層の地盤では, それぞれ 1.1 倍, 0.8 倍,
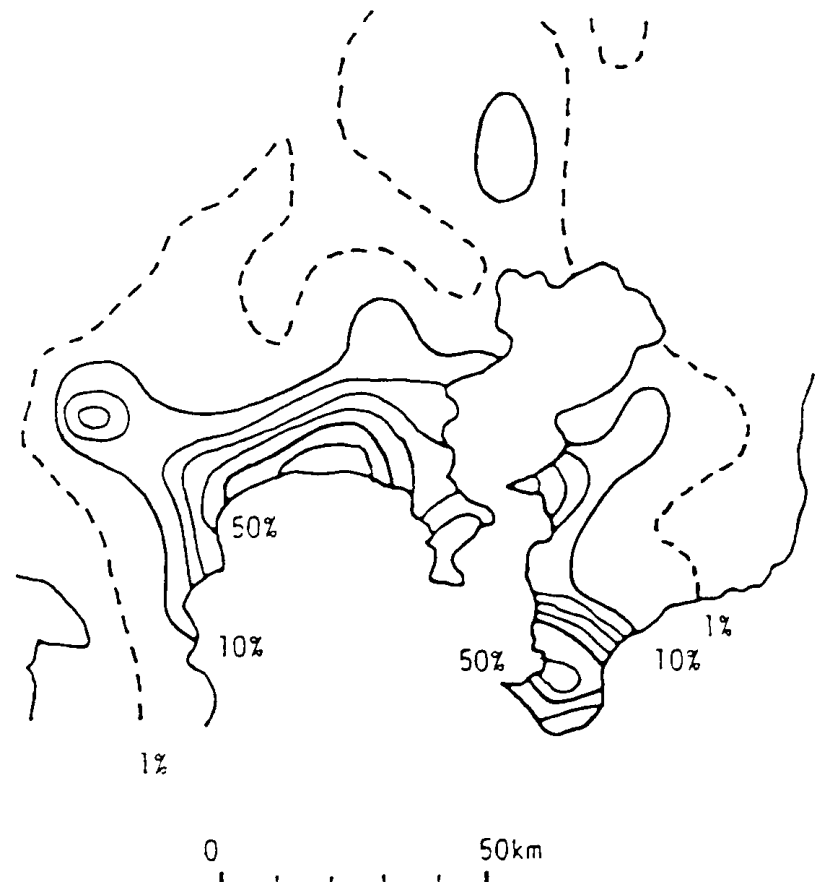

図一13 1923 年関東地霞の木造家屋の全壊率分布 (文献 21）による) 


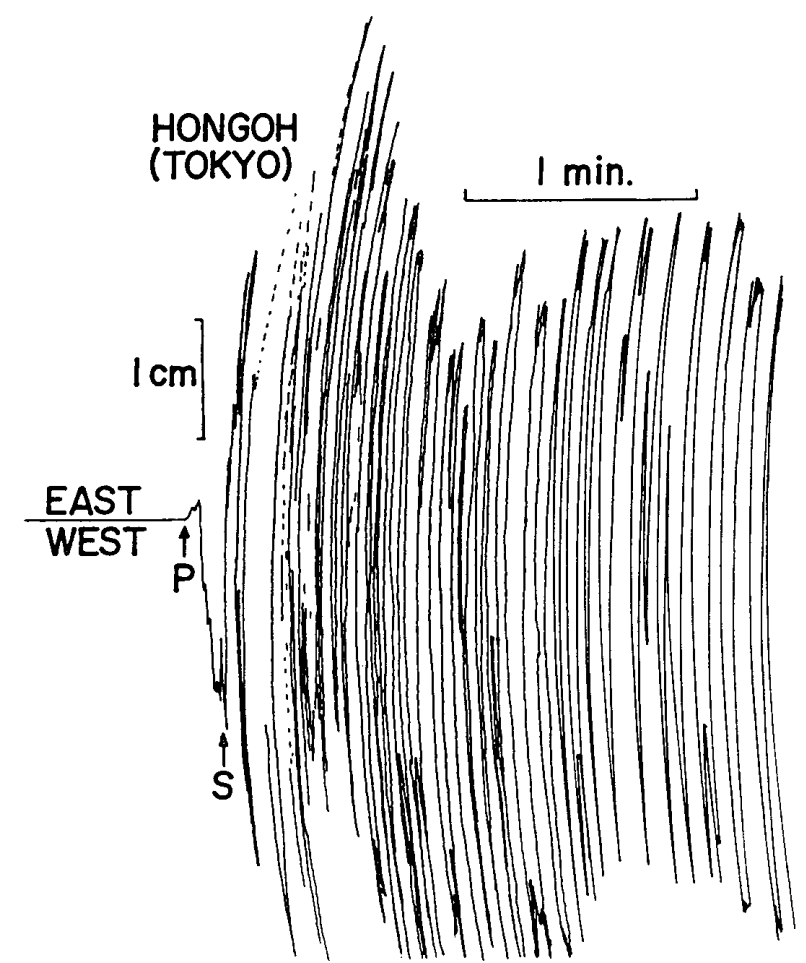

(a) OBSERVED DISPLACEMENT RECORD

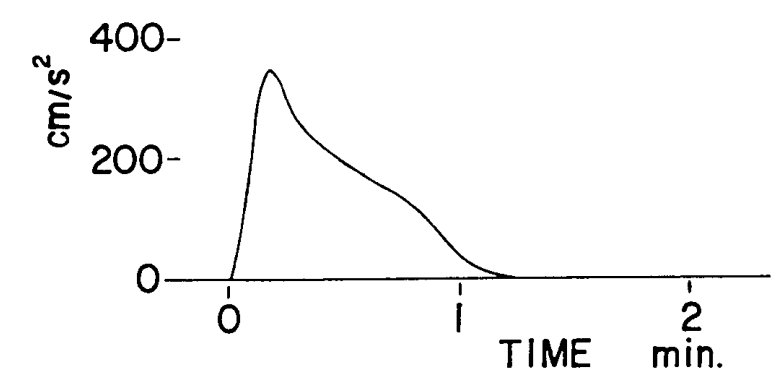

(b) CALCULATED ACCELERATION ENVELOPE

図一14 1923 年関東地震の東京本郷での観測変位記録 (a) と 計算された加速度包絡波形 (b) の比較

0.7 倍, 0.5 倍すれば地盤の増幅の効果を補正したこと になる。図一12に補正した最大加速度分布を示す。小 田原で $700 \mathrm{~cm} / \mathrm{s}^{2}$ 以上, 橫浜で $500 \mathrm{~cm} / \mathrm{s}^{2}$ 強, 東京で $400 \mathrm{~cm} / \mathrm{s}^{2}$ 弱の值が得られる。これらは，東京・本郷で のユーイング式地震計記録に基づく推定值約 $400 \mathrm{~cm} /$ $\mathrm{s}^{201}$ や図一13 に示した木造家屋の全壊率の分布 ${ }^{21)} と も$ おおむねよく対応している。ただし，埼玉県東部で計算 された最大加速度に比べ被害が大きいのは地震の液状化 により被害が増大したため敉と考えられる。

図一14に東京・本郷で観測された今村式強震計によ る変位記録 (EW 成分) と計算された加速度包絡波形 の比較を示す。変位記録において, P波初動から約 17 秒後, $\mathrm{S}$ 波初動からは約 7 秒後に地震計の針が飛んでし まい,その後の約 10 秒間は記録が欠落している。その後, 地震計の針は元に戻り，振り切れてはいるものの記録が 描かれている。また, 今村は, P波初動（初発）から 12 秒後に主要動を感じ, 初発から 15〜16 秒後に震動が
最大に達し，それが数秒ないし 10 秒間続き，その後， 震動は緩慢になったと報告している22)。したがって，S 波初動から数秒後に震動は最大となり，それが10 秒間 程度続いたことになる。図一14の（b）に示した計算さ れた加速度包絡波形の時刻 0 はS 波初動に対応すること を考えると, 計算結果は, 変位記録での針の飛びや記録 の振り切れた部分の様子および今村の観察をおおむねよ く説明している。

\section{6. 結 論}

余震合成法の合成規則を用いて，小地震の加速度包絡 波形を合成することにより大地震の最大加速度を推定す る簡便な手法を提案した。計算結果は, 距離の大きなと ころでは既往の距離減衰式と, 距離の小さなところでは, 断層付近での観測結果と，調和的な值を示し，本合成手 法の妥当性が確認できた。

標準的な断層面を持つ地震に対して本手法により計算 を行った結果，(1)断層付近での最大加速度は地震規模に ほとん亡゙依存しないこと, (2)低角断層の断層面の直上の 位置を除けば, 震源からの距離を断層面からの最短距離 で定義することにより，ある地震規模 $M$ に対する距離 減衰曲線は断層面の形状や方位によらずほぼ一義的に定 められること，(3)ただし，1 方向破壊伝搬の場合には， 破壞伝搬の効果も考慮する必要があること, (4)距離減衰 曲線の形状は地震規模により変化し, Campbell が用い た関数形で近似できること，がわかった。

さらに，断層面上で一様でない破壊分布を持つ地震に ついても計算を行い，実際の被害分布等と調和的な結果 が得られることがわかった。

\section{謝 辞}

本研究を始めるに際し，日本物理探鉱 中村 操氏と の議論は有益でした。また，原稿をまとめるに際し，東 工大 大町達夫教授との議論は有益でした。記して謝意 を表す次第である。

\section{参考文献}

1) K. Irikura : Semi-Empirical Estimation of Strong Ground Motions during Large Earthquakes, Bull. Disas. Prev. Res. Inst., Kyoto Univ., Vol. 33, pp. 63-104, 1983.

2) K. Irikura: Prediction of Strong Acceleration Motions Using Empirical Green's Function, Proc. 7th Japan Earthq. Eng. Sympo., pp. 151-156, 1986.

3）田中貞二·吉沢静代・坂上 実 ·大沢 胖：前・余震の 記録から本震地動の加速度波形特性を推定する一方法, 第 6 回日本地震工学シンポジウム講演集, pp.73-80, 1982.

4) K. Dan, T. Tanaka and T. Watanabe: Simulation and Prediction of Strong Ground Motion in Epicentral Region of the 1979 Imperial Valley Earthquake by Semiempirical Method, 日本建築学会構造系論文報告集, 第 373 号, pp. 50-62, 1987.

5）翠川三郎・小林啓美：地震断層を考虑した地震動スペク 
トルの推定, 日本建築学会論文報告集, 第 282 号, pp. 71-81, 1979.

6）翠川三郎・小林啓美：震源域及びその周辺での地表面最 大加速度分布の推定, 日本建築学会論文報告集, 第 290 号, pp. 83-94, 1980.

7）笠原慶一・中村 操・山田 真：小林・翠川の手法によ る多面断層の取扱い，地震学会講演予稿集, No. 1, p. 260, 1987.

8）小林啓美・翠川三郎・田鎖 隆：震源域周辺での地震基 盤からの入射波の強さについて，日本建築学会大会学術 講演梗概集, pp. 553-554, 1978.

9）田中貞二・福島美光：地震動強さの距離減衰，第 15 回地 盤震動シンポジウム資料集，pp.7-16，1987.

10) H. Kameda and M. Sugito : Prediction of Strong Earthquake Motions by Evolutionary Process Model, Proc. 5th Japan Earthq. Eng. Sympo., pp. 41-48, 1978.

11) World Data Center A for Solid Earth Geophysics: Digital Strong-Motion Data Magnetic Tape IVA, 1980.

12) Strong-Motion Earthquake Observation Council : Strong-Motion Earthquake Records in Japan (1983), Vol. 28, 1985.

13) M. J. Huang. D. L. Parke, R. W. Sherburne and A.F. Shakal : Processed Strong Motion Data from the Parm Springs Earthquake of 8 July 1986 Part I. GroundResponse Records, CSMIP Report No. OSMS 87-01, 1987.
14）佐藤良輔：断層パラメタ一間の関係式, 地震保険調查研 究 12，損害保険料率算定会，pp. 103-122， 1985.

15) K. Campbell : Near-Source Attenuation of Peak Horizontal Acceleration, Bull. Seism. Soc. Am., Vol.71, pp. 2039-2070, 1981.

16）表俊一郎・三宅昭春・楢橋秀衛：大地震時の震央域に於 ける地動最大加速度, 日本建築学会大会学術講演梗概集, pp. 463-464, 1979.

17) M. Kikuchi and Y. Fukao: Inversion of Long-period P-waves from Great Earthquakes along Subduction Zones, Tectophysics, Vol. 144, pp. 231-247, 1987.

18) M. Matsu'ura, T. Iwasaki, Y. Suzuki and R. Sato : Statical and Dynamical Study on Faulting Mechanism of the 1923 Kanto Earthquake, J. Phys. Earth, Vol. 28, pp. 119-143, 1980.

19）望月利男・宮野道雄・松田磐余：1923 年関東大地震にお ける木造家屋の被害の検討，日本建築学会論文報告集， 第 270号, pp. 81-90, 1978.

20）森岡敬樹：1923 年関東大地震の地動, 第 4 回地盤震動 シ ンポジウム資料集，pp. 39-48，1976.

21）鏡味洋史：空間的に分布する地震工学的データの自動化 表現, 第 6 回日本地震工学シンポジウム講演集, pp. 265-272, 1982.

22）今村明恒：関東大地震調查報告，震災予防調査会報告, 第百号 (甲)，pp. 21-65，1925.

\section{SYNOPSIS}

UDC : 550.34 .04

\section{SYNTHESIS OF GROUND ACCELERATION OF LARGE EARTHQUAKE USING ACCELERATION ENVELOPE WAVEFORM OF SMALL EARTHQUAKE}

by Dr. SABUROH MIDORIKAWA, Associate Professor, Tokyo Institute of Technology, Member of A. I. J.

A simplified method is proposed for synthesizing ground acceleration of large earthquake using acceleration envelope waveform of small earthquake. The fault plane of the large earthquake is divided into small elements which correspond to the small earthquake. The number of the elements is defined from the difference of magnitude between the large and small earthquakes. The acceleration envelope waveform from the small element is determined empirically from magnitude of the small earthquake and distance from the small element to an observation site. Since the acceleration time histories from the small elements should be incoherent each other, it could be considered that the acceleration envelope waveform of the large earthquake is equal to the square root of the sum of squares of the envelope waveforms from the small elements. The peak acceleration of the large earthquake is obtained from the maximum value of the summed envelope. Using this method, the peak accelerations are calculated for the earthquakes with different magnitude, and their attenuation characteristics are investigated. The result shows that 1 ) the shortest distance from fault plane is an appropriate definition of source distance, 2) the peak acceleration becomes independent of magnitude and distance in nearfield, 3) the functional form of the Campbell (1981)'s equation is fitted for the calculated attenuation curve, and 4) the source directivity effect is not negligible on the peak acceleration. The peak acceleration for the 1923 Kanto earthquake whose slip distribution is not uniform over the fault plane, is also calculated. 